\title{
Evaluation of the relationship between body composition and aerobic fitness in youth soccer players
}

\author{
Nalbant Ö. ${ }^{1 \mathrm{ABD}}$, Özer K. ${ }^{2 \mathrm{AC}}$ \\ ${ }^{1}$ Coaching Education Department, Alanya Alaaddin Keykubat University, Turkey \\ ${ }^{2}$ Coaching Education Department, Istanbul Gedik University, Turkey
}

Authors' Contribution: A - Study design; B - Data collection; C - Statistical analysis; D - Manuscript Preparation; E - Funds Collection.

\begin{abstract}
Purpose: $\quad$ The purpose of the study was to make an evaluation between aerobic fitnes (VO2max) and body composition in youth soccer players.

Material: $\quad$ U19, U17, U16 and U15 age groups participated in the study. Twenty-eight U19 (average age 18,03 $\pm 0,58$ ),

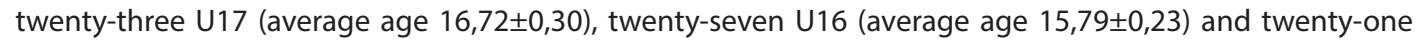
U15 (average age 14,67 $\pm 0,31$ ) totally ninety-nine athletes voluntarily participated in the study. The subjects' body weight and fat percentage were estimated by bioelectrical impedance. VO2max was determined by YOYO Intermittan Recovery test protocol. Shapiro-wilk test, Independent t test, hierarchical regression and analysis of covariance were used to compare the relationships between aerobic fitness and body composition. Additionally, Pearson correlation coefficients were calculated to examine the relationships between variables. The level of significance for all statistics was set at $p<0.05$. SPSS 23 software was used to calculate the data. The total value of all estimators is $f=18,001$ and $p<0.0001$.

Results: $\quad$ Although all variables were included in the model, the BMI was considered the greatest explanatory factor for fatness. Aerobic endurance was assessed in direct proportion to age, sit and reach test, crunch test, plank, and long jump test. As the distance increased, the $\%$ fat ratio decreased $(p<0.001)$, and the fat ratio decreased with the decrease in the T test $(p<0.001)$.

Conclusions: In this study, it was determined that body fat ratio determined by BMI, body fat percentage decreased with increasing aerobic endurance, body fat ratio was negatively correlated with aerobic fitness and lean body ratio. It was also determined that aerobic fitness was positively correlated with age, sit and reach, crunch test, plank, standing long jump and T test.

Keywords: $\quad$ aerobic fitness, body composition, fat percentage, soccer, training, YOYO.
\end{abstract}

\section{Introduction}

Aerobic endurance is an important factor of success in sports achievements. And this status generaly considered for determiner of cardio respiratory fitness. VO2max refers to the intensity of aerobic process, maximum capacity and consumption oxygen during exercise [1]. Aerobic fitness is the main factors that enhance human to doing daily jobs and also improve the ability to long time duration exercise [2]. Body composition is also a very important factor for many sports disciplines. Components such as muscle mass, stamina and speed are the effects of body composition on the athlete [3].

Physical activity also has an impact on work capacity and body composition. It is known that the basal metabolic rate, $\mathrm{VO} 2 \mathrm{max}$, and hemodynamic responses to exercise are stronger than fat-free mass and total body mass [4]. Therefore, those participating in sports activities exhibit a higher level of physical activity than those who do not participate $[5,6]$.

On the other hand, low physical activity does not only lead to nonconformities in the physical structure, but at the same time immobility leads to diseases such as cholesterol, hypertension, diabetus and cardiovascular diseases in both adults and children [7]. In addition, children have a higher level of physical fitness at a better level than at a higher level.

(c) Nalbant Ö., Özer K., 2018

doi:10.15561/20755279.2018.0505
From these views, it has not been found out that studies on body compositions and aerobics fitness of soccer players of different age groups. The aim of this study is to evaluate the relation between aerobic fitness and body composition in young soccer players.

\section{Material and Methods}

Participants

U19, U17, U16 and U15 age group soccer players participated in the study. Twenty-eight U19 (average age $18,03 \pm 0,58$ year; height $178,12 \pm 5,29$; weight $69,89 \pm 6,50$; training experience $8,18 \pm 1,39$ ), twenty-three U17 (average age $16,72 \pm 0,30$; height $176,65 \pm 4,92$; weight $65,94 \pm 6,11$; training experience $6,74 \pm 1,51$ ), twenty-seven U16 (average age 15,79 $\pm 0,23$; height 178,81 $\pm 5,08$; weight $68,01 \pm 7,24$; training experience $4,74 \pm 1,32$ )

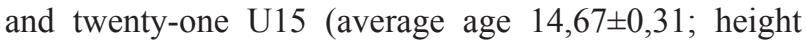
$172,33 \pm 7,34$; weight $60,76 \pm 8,73$; training experience $3,95 \pm 1,20)$ totally ninety-nine athletes voluntarily participated in this study. The athletes were asked not to participate in a daily training program within 24 hours prior to testing. Testing was completed for all athletes in the same laboratory and field facilities. All athletes and parents were notified of the research procedures, requirements, benefits, and risks before giving informed consent and written informed consent was obtained from all the participants and their parents. Testing and measurements were made when entering the football season. The study 
was conducted in a manner consistent with the institutional ethical requirements for human experimentation in accordance with the Declaration of Helsinki.

\section{Measures}

Measurements of Height and Body Weight

Body height and weight measurements were made using a digital scale (Seca 664, Hamburg, Germany) in bare feet and wearing only shorts. The body mass index (BMI) of each soccer players were calculated as weight in $\mathrm{kg}$ divided by weight in meters squared.

Assessment of Body Composition

In this study, a BC-418 8-contact electrode BIA system (Tanita Corp., Tokyo, Japan) was used to determine body composition. Body fat percentage and fat free mass were obtained by using this device.

Aerobic endurance tests (maximum oxygen uptake capacity (VO2max)

YOYO Intermittan Recovery test protocol

Yo-Yo Intermittent Recovery 1 (Yo-Yo Irt 1) is a field test and performs intermittent loads. This test was designed to measure aerobic capacity and the amount of VO2max used by athletes [8]. This test applied to footballers was made on the football ground. The test is a $20+$ $5 \mathrm{~m}$ field athlete running at $8 \mathrm{~km} / \mathrm{h}$ and the running speed is increasing. The rest period of the test is 10 seconds at $40 \mathrm{~m}$ every time until the end of the test. The athletes move according to the signal sounds coming from the $20 \mathrm{~m}$ test run, and they complete the round by moving in and out. The $+5 \mathrm{~m}$ distance in the test area is the resting interval that can be taken for 10s in each round. The test of the athlete who can not reach the area marked on the top twice shall be terminated. The number of rounds for which the athlete last ran is recorded in distance. This distance is used to calculate the $\mathrm{VO} 2 \mathrm{max}$ value. The $\mathrm{VO} 2 \mathrm{max}$ value of the athlete is calculated by the following formula.

$$
\mathrm{VO}_{2} \max =\text { distance }(\mathrm{m}) \times 0.0084+36.4
$$

Sit and reach test: The athlete sat by his feet in front of the table for measurement. While he was in this position, he extended his body as far as possible, slowly pushed the table down and stopped at the end. The test is repeated twice and the best of both measurements was recorded [9].

Standing long jumping test: During testing in the beginning of a steel metric placed on a line of subjects ' 0 ', the meter strip was centered between two feet. They wanted to jump the longest distance they could jump from the subjects. After the jump, the last points left of the subjects were determined and measured. In order for the measurements to be reliable, the subjects performed the test twice. The best measurement was recorded [10].

10 Meter and 30 meter speed test: Photocell is placed at the beginning and end of $10 \mathrm{~m}$ and $30 \mathrm{~m}$ tracks. Participants start a speed run $50 \mathrm{~cm}$ behind the start line. Two trials were conducted and the best score was recorded [11].

Crunch test: Lying on the back, the hands are consolidated on the hand. The knees were placed in a pulled position (with the knees at 90 degrees), with the bases fully grounded. Towards the top, the elbows had to come forward and the knees were touched at the end of the move. During the entire movement, it was noted that the hands were joined to the ensemble. At the beginning of the movement again the shoulders were at the mind. Within 30 seconds, this movement was tried to be repeated as many times as possible [12].

Sport-specific endurance plank test: Participants started the test by holding a basic plank position e a prone bridge supported by the forearms and feet. Elbows were vertically below the shoulders with the forearms and fingers extending straight forward. The neck was kept neutral so that the body remained straight from the head to the heels. Participants were required to maintain the prone bridge in a good form. It should try to protect this position as much as possible. The result was recorded as time [13].

T-Test: The T-Test was administered using a version standardized from previous literature [14]. The units of measurement were changed from yards to meters, creating a $10 \times 10 \mathrm{~m}$ course. The course procedure of having the participant touch each cone is not standardized in the literature; therefore, the task was eliminated. The directions adopted for this study were based on Miller et al. On the "go" command, the participant (1) ran or moved as quickly as possible forward to the center cone, (2) sidestepped to the right $5 \mathrm{~m}$ to the right cone, (3) sidestepped to the left $10 \mathrm{~m}$ to the far left cone, and then (1) sidestepped back to the right to the center cone. The participant then ran or moved backward as quickly as possible to cross the finish line. The raters began the stop watch on "go" and stopped when the participant broke the plane of the finish line. The time to complete each trial was recorded in seconds. Disqualification was determined if the participant failed to run the course as instructed, failed to reach the finish line or complete the course, moved any cones, did not keep his trunk and feet pointed forward at all times, or crossed his legs more than once when sidestepping. If a participant did not complete a trial successfully, a score of 0 was given [15].

\section{Procedures}

The athletes participate in training programs of 1.5hour exercise in a day, 4 days per week done match during the season. The season was divided into three training parts, such as season preparatory period, preliminary competition period and competition period. All measurements were made in the preliminary competition period and between 8:00 and 12:00 a.m. in order to have similar chronobiological characteristics [16]. All measurements were performed by same researchers in morning times and American College of Sports Medicine Guidelines test prosedures were followed [17].

Statistical Analysis.

Before analysis, normality and equality of variance of the variables were assessed using a Shapiro-wilk test. The differences between age groups were determined using the Independent t test. Hierarchical Regression and analysis of covariance were used to compare the relationships between aerobic fitness and body composition. Additionally, Pearson correlation coefficients were calculated to 
examine the relationships between variables. The level of significance for all statistics was set at $p<0.05$. SPSS 23 , software was used to calculate the data.

\section{Results}

In our study, data on the performance of football players were obtained and the evaluations are shown in the following tables. The descriptive data (mean and standard deviation) of the measured variables including age, sport age, height, weight, BMI, \%fat, sit and reach, shuttle, plank, standing long jump, $10 \mathrm{~m}$ speed, $30 \mathrm{~m}$ speed, $\mathrm{t}$ test, aerobic endurance and Vo2max are shown in Table 1 , and the results of statistical analysis and corelation of measured variables are shown in Table 6.

The dependent variable fat $\%$ description ratio of all arguments is adjusted $\mathrm{R}^{2}=0.50$ (Table 2)

The total value of all predictors was found to be $\mathrm{f}=$ 18,001 and $p<0,0001$ (Table 3).

Although all variables are included in the model, the $\mathrm{BMI}$ is considered to be the greatest predictor of fatness ratio (Table 4).
The aerobic endurance was found to be directly proportional to age, sit-up, crunch test, plank, and standing long jump test (Table 5).

\section{Discussion}

The determination of VO2max can be done by experienced personnel and high budgets in various laboratory environments. However, this is not appropriate for some applications [18]. For this reason, there are some tests that sports scientists can use and in which athletes can predict maximum oxygen uptake.

In this study, when all variables were included in the model, the finding that best explains the fatness ratio is the BMI. Goran et al. reported that maximal aerobic capacity was significantly lower in the obese children, as indicated by a higher $\mathrm{HR}$ and $\% \mathrm{VO} 2 \mathrm{max}$; time to exhaustion was significantly lower in the obese children. Also said that FM does not have any effect on VO2max. Fatness and excess body weight do not necessarily imply a reduced ability to maximally consume oxygen, but excess fatness does have a detrimental effect on submaximal aerobic ca-

Table 1. Test measurement results of the groups

\begin{tabular}{lllll}
\hline GROUPS & $\mathbf{U 1 9}(\mathbf{N}=\mathbf{2 8})$ & $\mathbf{U 1 7}(\mathbf{N}=\mathbf{2 3})$ & $\mathbf{U 1 6}(\mathbf{N}=\mathbf{2 7})$ & $\mathbf{U 1 5}(\mathbf{N}=\mathbf{2 1})$ \\
Measurements & $\mathbf{X} \pm \mathbf{S D}$ & $\mathbf{X} \pm$ SD & $\mathbf{X} \pm \mathbf{S D}$ & $\mathbf{X} \pm$ SD \\
\hline Age & $18,03 \pm 0,5$ & $16,72 \pm 0,3$ & $15,79 \pm 0,2$ & $14,67 \pm 0,3$ \\
Sports age & $8,18 \pm 1,3$ & $6,74 \pm 1,5$ & $4,74 \pm 1,3$ & $3,95 \pm 1,2$ \\
Height & $178,12 \pm 5,2$ & $176,65 \pm 4,9$ & $178,81 \pm 5,0$ & $172,33 \pm 7,3$ \\
Weight & $69,89 \pm 6,5$ & $65,94 \pm 6,1$ & $68,01 \pm 7,2$ & $60,76 \pm 8,7$ \\
BMI & $22,03 \pm 1,8$ & $21,11 \pm 1,7$ & $21,25 \pm 1,8$ & $20,37 \pm 1,7$ \\
\%Fat & $12,82 \pm 4,7$ & $14,89 \pm 2,2$ & $17,09 \pm 3,4$ & $15,61 \pm 2,8$ \\
Sit and Reach & $37,23 \pm 5,2$ & $32,80 \pm 4,8$ & $33,50 \pm 6,2$ & $32,67 \pm 5,8$ \\
Crunch Test & $51,31 \pm 7,4$ & $49,75 \pm 8,6$ & $45,50 \pm 5,1$ & $48,89 \pm 5,5$ \\
Plank & $131,28 \pm 7,8$ & $177,17 \pm 5,2$ & $167,94 \pm 5,3$ & $184,83 \pm 5,7$ \\
Standing Long Jump & $2,16 \pm 0,1$ & $2,07 \pm 0,1$ & $2,05 \pm 0,2$ & $1,93 \pm 0,2$ \\
10 m Speed & $1,76 \pm 0,1$ & $1,71 \pm 0,1$ & $1,71 \pm 0,1$ & $1,89 \pm 0,0$ \\
30 m Speed & $4,32 \pm 0,4$ & $4,20 \pm 0,1$ & $4,26 \pm 0,1$ & $4,52 \pm 0,2$ \\
Ttest & $9,26 \pm 0,4$ & $7,90 \pm 0,2$ & $9,14 \pm 0,6$ & $9,03 \pm 0,3$ \\
Aerobic Endurance & $1544,44 \pm 40,1$ & $1366,67 \pm 40,8$ & $1215,00 \pm 36,6$ & $1184,44 \pm 38,9$ \\
Vo2max & $49,50 \pm 3,5$ & $47,58 \pm 3,4$ & $46,67 \pm 3,1$ & $46,41 \pm 3,1$ \\
\hline
\end{tabular}

Table 2. Regression model evaluation regression analysis for estimation of fat\%

\begin{tabular}{lllll}
\hline Model & R & R Square & Adjusted R Square & Std. Error of the Estimate \\
\hline 1 &, $409^{\mathrm{a}}$ &, 167 &, 155 & 3,4167 \\
2 &, $654^{\mathrm{b}}$ &, 427 &, 410 & 2,8554 \\
3 &, $695^{\mathrm{c}}$ &, 484 &, 460 & 2,7319 \\
4 &, $728^{\mathrm{d}}$ &, 529 &, 500 & 2,6282 \\
\hline
\end{tabular}

a. Predictors: (Constant), age; b. Predictors: (Constant), age, bmi; c. Predictors: (Constant), age, bmi, Pla; d. Predictors: (Constant),age, bmi, Pla, End. 
Table 3. Anova test evaluated of regression analysis for estimation of fat\%

\begin{tabular}{|c|c|c|c|c|c|c|}
\hline \multicolumn{2}{|c|}{ Model } & \multirow{2}{*}{$\begin{array}{l}\text { Sum of Squares } \\
157,258\end{array}$} & \multirow{2}{*}{$\begin{array}{l}\mathbf{d f} \\
1\end{array}$} & \multirow{2}{*}{$\begin{array}{l}\text { Mean Square } \\
157,258\end{array}$} & \multirow{2}{*}{$\begin{array}{l}\text { F } \\
13,471\end{array}$} & \multirow{2}{*}{$\begin{array}{l}\text { Sig. } \\
, 000^{b}\end{array}$} \\
\hline & Regression & & & & & \\
\hline 1 & Residual & 782,155 & 67 & 11,674 & & \\
\hline & Total & 939,413 & 68 & & & \\
\hline \multirow{3}{*}{2} & Regression & 401,299 & 2 & 200,649 & 24,610 &, $000^{c}$ \\
\hline & Residual & 538,115 & 66 & 8,153 & & \\
\hline & Total & 939,413 & 68 & & & \\
\hline \multirow{3}{*}{3} & Regression & 454,290 & 3 & 151,430 & 20,290 &, $000^{d}$ \\
\hline & Residual & 485,123 & 65 & 7,463 & & \\
\hline & Total & 939,413 & 68 & & & \\
\hline \multirow{3}{*}{4} & Regression & 497,344 & 4 & 124,336 & 18,001 &, $000^{e}$ \\
\hline & Residual & 442,069 & 64 & 6,907 & & \\
\hline & Total & 939,413 & 68 & & & \\
\hline
\end{tabular}

a. Dependent Variable: fat; b. Predictors: (Constant), age; c. Predictors: (Constant), age, bmi; d. Predictors: (Constant), age, bmi, Pla; e. Predictors: (Constant), age, bmi, Pla, End.

Table 4. Coefficients

\begin{tabular}{|c|c|c|c|c|c|c|}
\hline \multirow{2}{*}{\multicolumn{2}{|c|}{ Model }} & \multicolumn{2}{|c|}{ Unstandardized Coefficients } & \multirow{2}{*}{$\begin{array}{l}\text { Standardized } \\
\text { Coefficients } \\
\text { Beta }\end{array}$} & \multirow[t]{2}{*}{$\mathbf{t}$} & \multirow[t]{2}{*}{ Sig. } \\
\hline & & B & Std. Error & & & \\
\hline \multirow{2}{*}{1} & (Constant) & 33,158 & 4,973 & & 6,667 & ,000 \\
\hline & Age & $-1,114$ & ,303 &,- 409 & $-3,670$ & ,000 \\
\hline \multirow{3}{*}{2} & (Constant) & 17,885 & 5,007 & & 3,572 & ,001 \\
\hline & Age & $-1,629$ & 271 &,- 598 & $-6,022$ & ,000 \\
\hline & $\mathrm{BMI}$ & 1,120 & ,205 & ,544 & 5,471 & ,000 \\
\hline \multirow{4}{*}{3} & (Constant) & 22,191 & 5,056 & & 4,389 &, 000 \\
\hline & Age & $-1,669$ & ,259 &,- 613 & $-6,436$ & ,000 \\
\hline & $\mathrm{BMI}$ & 1,061 & 197 & ,515 & 5,386 & ,000 \\
\hline & Pla &,- 014 & ,005 &,- 240 & $-2,665$ & 010 \\
\hline \multirow{5}{*}{4} & (Constant) & 23,115 & 4,878 & & 4,739 & ,000 \\
\hline & Age & $-1,345$ & 281 &,- 494 & $-4,781$ & ,000 \\
\hline & $\mathrm{BMI}$ & ,885 & 202 & ,429 & 4,370 & ,000 \\
\hline & Pla &,- 011 & ,005 &,- 187 & $-2,098$ & ,040 \\
\hline & End &,- 002 & ,001 &,- 251 & $-2,497$ & ,015 \\
\hline
\end{tabular}

a. Dependent Variable: fat

pacity [19]. Thus, fatness and VO2max should be considered independent entities. Also, as the tests and measurements were made as they entered the football season, they were physically and conditionally ready, which confirmed the accuracy of the measurements made. Silvestre et al. reported also that soccer athletes who begin a season with a high level of fitness can maintain, and in some cases improve, body composition and physical performance from before to after a competitive season. A correct combination of soccer-specific practices and strength and conditioning programs can maintain and develop physi- cal performance [20]. Nikolaidis also pointed out the relationship between BMI and fat ratio and mentioned the adverse effects of excessive weight on adolescent soccer players. For oil control, it also offers personalized work with proper training planning [21]. In addition, Silva et al. reported that most of the findings from European football studies have the highest VO2max values of midfield players [22].

Another finding in the study is reduced body fat percentage as aerobic endurance increases. Denger and his colleagues conducted a study on girls and boys. Accord- 
Table 5. Relationship between aerobic endurance and some parameters

\begin{tabular}{lll}
\hline Parameters & $\mathbf{r}$ & $\mathbf{p}$ \\
\hline Age &, $328^{* *}$ &, 000 \\
\%Fat &,$- 564^{* *}$ &, 000 \\
Sit and Reach &, $251^{* *}$ &, 004 \\
Crunch Test &, $415^{* *}$ &, 000 \\
Plank &, $303^{* *}$ &, 000 \\
Standing Long Jump &, $229^{* *}$ &, 008 \\
Ttest &,$- 336^{* *}$ &, 001 \\
\hline
\end{tabular}

**. Correlation is significant at the 0.01 level (2-tailed).

Table 6. The results of statistical analysis and corelation of measured variables

\begin{tabular}{|c|c|c|c|c|c|c|}
\hline \multirow{2}{*}{ Model } & & \multicolumn{2}{|c|}{ Unstandardized Coefficients } & \multirow{2}{*}{$\begin{array}{l}\text { Standardized Coefficients } \\
\text { Beta }\end{array}$} & \multirow{2}{*}{$\mathbf{t}$} & \multirow{2}{*}{ Sig. } \\
\hline & & B & Std. Error & & & \\
\hline \multirow{2}{*}{1} & (Constant) & 2589,147 & 277,335 & & 9,336 & 000 \\
\hline & fat & $-80,761$ & 17,047 &,- 564 & $-4,738$ & ,000 \\
\hline
\end{tabular}

Fat $\%$

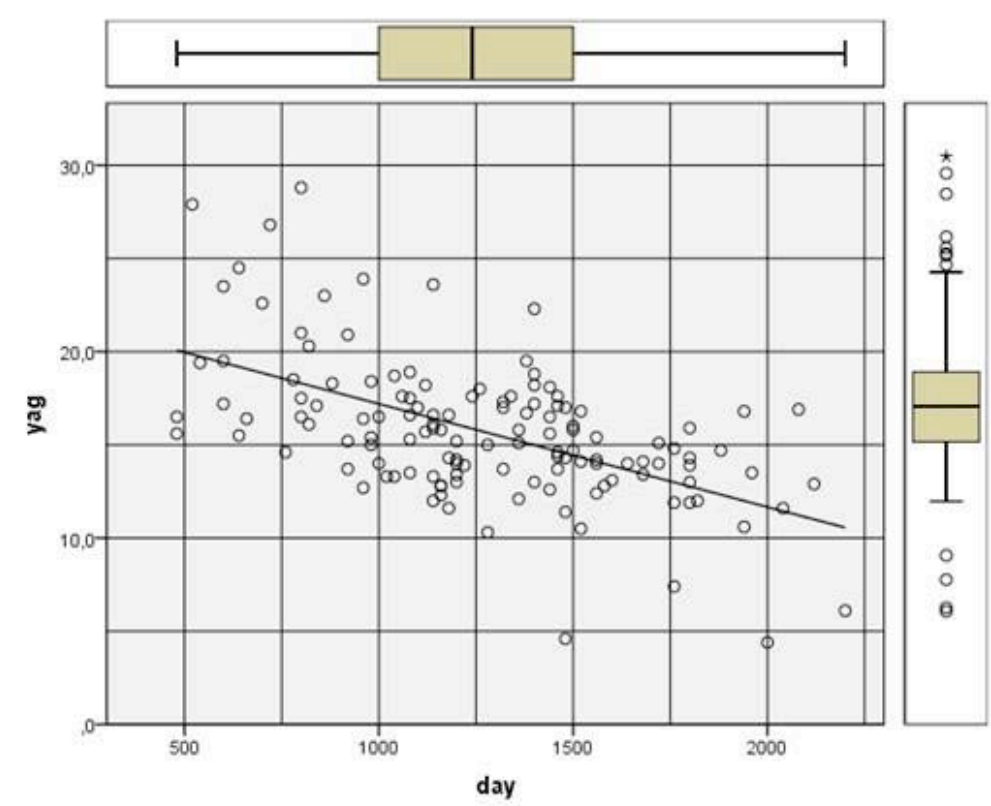

Aerobic Endurance

Figure 1. Relationship graph between aerobic endurance and fat\%.

ing to this study, boys with better aerobic endurance said that body fat ratios were better than girls [23]. In another study of Nikolaidis, the weight of footballers was similar to that of the general population, and the durability was inversely proportional to the body fat ratio [24]. Therefore, giving importance to body composition of soccer players will contribute to aerobics suitability. Overweight is also known to have negative effects on physical fitness. Minasian and colleagues found that females had a fat ratio of $24.73 \%$ and an aerobic fitness of $29.5(\mathrm{ml} / \mathrm{kg} / \mathrm{min})$ and a male fat ratio of $19.32 \%$ and an aerobic fitness of 36.4 ( $\mathrm{ml} / \mathrm{kg} / \mathrm{min})$ in girls and boys. Results also revealed that there was a negative significant correlation between fat percent and aerobic fitness of boys $(r=-0.81)$, and girls $(\mathrm{r}=-0.77)$ respectively [25]. This result reveals the conclusion we have determined between fat ratio and aerobic fitness.

The results of the study and other studies indicate that the fat ratio (\% Fat) is negatively related to aerobic fitness and the lean body ratio (FFM) is positively associated with aerobic endurance. Reducing the fat percentage and increasing the lean body ratio is important to achieve high VO2max. The different study results clearly show that \%Fat and FFM have not only an aerobic endurance but also a great effect on anaerobic and muscle strength $[26,27]$.

A significant relationship was found between aerobic fitness and age $(r=0.328, p<0.01)$, fat $\%(r=-0.558$, $\mathrm{p}<0.01)$, sit and reach $(\mathrm{r}=0.251, \mathrm{p}<0.01)$; crunch test $(\mathrm{r}=0,415 ; \mathrm{p}<0.01)$; plank $(\mathrm{r}=0.303, \mathrm{p}<0.01)$; standing 
long jump $(\mathrm{r}=0,229 ; \mathrm{p}<0,01)$ and $\mathrm{T}$ Test $(\mathrm{r}=-0,336 ; \mathrm{p}$ $<0,01$ ) (Table 5). This shows us that these parameters are directly proportional to aerobic fitness according to the results of these tests. Demirkan and colleagues found that the participant's body fat percentage (FP), free fat mass (FFM) and basal metabolic rate (BMR) were calculated by bioelectrical impedance. Also, VO2max values were determined by the 12-minute walk study and multistage running tests (MST). According to the results obtained, boys and girls who have been trained have high VO2max values but boys have better values [28]. Czajkowska et al. conducted a study to evaluate the relationship between anthropometric and cardiovascular characteristics and aerobic capacity. They also noted that participants in the study also differed in physical activity levels according to resting and exercise conditions. When the relationship between physical activity and physiological characteristics was determined, it was found that Vo2max value was an important factor [29]. Campos-Vazquez et al. reported that Maxvo2 and heart rate could be different, depending on the intensity of the soccer players loading in different seasons and weeks [30]. This is also an important information. On the contrary, Christopher and Emmanuel noted that the measurements did not show seasonal and temporal differences, and that differences existed according to positions [31].

\section{Conclusions}

In this study, it was determined that body fat ratio determined by BMI, body fat percentage decreased with increasing aerobic endurance, body fat ratio was negatively correlated with aerobic fitness and lean body ratio. It was also determined that aerobic fitness was positively correlated with age, sit and reach, crunch test, plank, standing long jump and $\mathrm{T}$ test.

\section{Conflict of interest}

The authors declare no conflict of interest.

\section{References}

1. Shete AN, Bute SS, Deshmukh P. A Study of VO2max and Body Fat Percentage in Female Athletes. Journal of Clinical and Diagnostic Research, 2014; 8(12), BC01-BC03.

2. Amani, A.R, Somchit, M.N, Konting, M.M.B, Kok L.Y. Relationship between Body Fat Percent and Maximal Oxygen Uptake among Young Adults. Journal of American Science, 2010;6(4), 1-4.

3. Maciejczyk M, Więcek M, Szymura J, Szyguła Z, Wiecha S, Cempla J. The influence of increased body fat or lean body mass on aerobic performance. PLoS One, 2014; 21;9(4), e95797.

4. Lohman TG, Ring K, Pfeifer K, Camhi S, Arredondo E, Pratt $\mathrm{CH}$, Pate R, Webber LS. Relationship among fitness, body composition, and physical activity. Meicine Science and Sports and Exercise, 2008; 40:1163-1170.

5. Mazurek K, Wit B, Mróz A, Wiśniewska M, Klukowski K. Health positive behavior of students Warsaw Physical Education Academy and cardiovascular diseases risk. Medicina Sportiva 8(Suppl. 2):2004; S69-S70.

6. Suder A, Gwardiak T. Differentiation of fatty features and fat tissue distribution in students of physical education and tourism direction of Physical Education Academy in Cracow. Phyical Education and Sport, 2003; 47:275-287.

7. King AC, Parkinson KN, Adamson AJ, Murray L, Besson H, Reilly J. Correlates of objectively measured physical activity and sedentary behaviour in English children. Europan Journal of Public Health, 2011;21:424- 31.

8. Bangsbo J, Marcello IF, Krustrup P. The Yo-Yo Intermittent Recovery Test. Sports Medicine; 2008; 1: 38 37,51.

9. Wells K, Dillon EK. The Sit and Reach-A Test of Back and Leg Flexibility. Research Quarterly. American Association for Health, Physical Education and Recreation. 2013;23:115118.

10.Porter JM, Ostrowski EJ, Nolan RP, Wu WFW. Standing Long-Jump Performance is Enhanced when Using an External Focus of Attention. The Journal of Strength \& Conditioning Research. 2010; 24(7): 1746-1750.

11.Buchheit M. The 30-15 Intermittent Fitness Test: Accuracy for Individualizing Interval Training of Young Intermittent Sport Players. The Journal of Strength \& Conditioning Research. 2008; 22(2):365-374.
12.Colado JC, Triplett NT, Tella V, Saucedo P, Abellan J. Effects of aquatic resistance training on health and fitness in postmenopausal women. European Journal of Applied Physiology. 2009;106(1):113-122.

13.Tong TK, Wu S, Nie J. Sport-specific endurance plank test for evaluation of global core muscle funct tion. Physical Therapy in Sport, 2013;15:58-63.

14. Miller MG, Herniman JJ, Ricard MD, Cheatham CC, Michael TJ. The effects of a 6-week plyometric training program on agility. Journal of Sports Science and Medicine, 2006;5(3):459-65.

15.Raya AM, Gailey SR, Gaunaurd AI, Jayne MD, Campbell MS, Gagne E, Manrique GP, Muller GD, Tucker C. Comparison of three agility tests with male servicemembers: Edgren Side Step Test, T-Test, and Illinois Agility Test. Journal of Rehabilitation Research and Development, 2013;50(7):951-960.

16.Drust B, Waterhouse J, Atkinson G, Edwards B, Reilly, T. Circadian rhythms in sports performance- An update. Chronobiology International, 2005; 22(1): 21-44.

17.ACSM's guidelines for exercise testing and prescription. American College of Sports Medicine. Lippincott Williams \& Wilkins; 2010.

18.Aziz AR, Tan FHY, Teh KC. Pilot study comparing two field tests with the treadmill run test in soccer players. Journal of Sports Science and Medicine, 2005;4:105-112.

19.Goran M, Fields DA, Hunter GR, Herd SL, Weinsier RL. Total body fat does not influence maximal aerobic capacity. International Journal of Obesity, 2000; 24(7):841-8.

20.Silvestre R, Kraemer WJ, West C, Judelson DA, Spiering BA, Vingren JL, Hatfield DL, Anderson JM, Maresh CM. Body composition and physical performance during a National Collegiate Athletic Association Division I men's soccer season. Journal of Strength and Condition Research. 2006; 20(4):962-70.

21.Nikolaidis PT. Elevated Body Mass Index and Body Fat Percentage Are Associated with Decreased Physical Fitness in Soccer Players Aged 12-14 Years. Asian Journal Sports Medicine, 2012; 3(3): 168-174.

22.Silva CD, Bloomfield J, Marins JCB. A Review of Stature, Body Mass and Maximal Oxygen Uptake Profiles of U17, U20 and First Division Players in Brazilian Soccer. Journal 
of Sports Science and Medicine, 2008; 7(3): 309-319.

23.Dencker M, Thorsson O, Karlsson MK, Lindén C, Eiberg S, Wollmer Andersen LB. Gender differences and determinants of aerobic fitness in children aged 8-11 years. Euro Journal Apply Physiology, 2007; 99(1):19-26.

24.Nikolaidis PT. Physical fitness is inversely related with body mass index and body fat percentage in soccer players aged 16-18 years. Medicinski Pregled, 2012; 65(11-12):470-5.

25.Minasian V, Marandi SM, Kelishadi R, Abolhassani H. Correlation between Aerobic Fitness and Body Composition in Middle School Students. International Journal Preventive Medicine, 2014; 5(Suppl 2): S102-S107.

26.Kim J, Cho HC, Jung HS, Yoon JD. Influence of performance level on anaerobic power and body composition in elite male judoists. Journal and Strength and Condition Research, 2011; 25(5): 1346-1354.

27.Hegge AM, Myhre K, Welde B, Holmberg HC, Sandbakk $\mathrm{O}$. Are gender differences in upper-body power generated by elite cross-country skiers augmented by increasing the intensity of exercise? PLoS One, 2015; 22, 10(5): 1-16.
28.Demirkan E, Can S, Arslan E. The Relationship between Body Composition and Aerobic Fitness in Boys and Girls Distance Runners. International Journal of Sports Science, 2016; 6(2): 62-65.

29.Czajkowska A, Mazurek K, Lutoslawska G, Zmijewski Z. Anthropometric and cardio-respiratory indices and aerobic capacity of male and female students. Biomedical Human Kinetics, 2009; 1: $47-51$.

30.Campos-Vazquez MA, Mendez-Villanueva A, GonzalezJurado JA, León-Prados JA, Santalla A, Suarez-Arrones L. Relationships between rating-of-perceived-exertion- and heart-rate-derived internal training load in professional soccer players: a comparison of on-field integrated training sessions. International Journal of Sports Physiology and Performance, 2015; 10(5):587-92.

31.Christopher C, Emmanuel O. Variation in Body Composition in Professional Soccer Players: Interseasonal and Intraseasonal Changes and the Effects of Exposure Time and Player Position. Journal of Strength \& Conditioning Research, 2010;24(5):1332-1339.

\section{Information about the authors:}

Nalbant Ö.; http://orcid.org/0000-0002-2727-3522; ozgur.nalbant@alanya.edu.tr; Coaching Education Department, Alanya Alaaddin Keykubat University; Kestel Mahallesi Konya Çimento Caddesi No:80, 07400 Alanya/Antalya, Turkey.

Özer K.; (Corresponding author); http://orcid.org/0000-0001-9913-5084; ozgur.nalbant@alanya.edu.tr; Coaching Education Department, İstanbul Gedik University; Çamlık Mahallesi Nazende Sokak No: 2 Çamlık Spor Tesisleri Karşısı Kurtköy İstanbul, Turkey.

Cite this article as: Nalbant Ö, Özer K. Evaluation of the relationship between body composition and aerobic fitness in youth soccer players. Physical education of students, 2018;22(5):258-264. doi:10.15561/20755279.2018.0505

The electronic version of this article is the complete one and can be found online at: http://www.sportedu.org.ua/index.php/PES/issue/archive

This is an Open Access article distributed under the terms of the Creative Commons Attribution License, which permits unrestricted use, distribution, and reproduction in any medium, provided the original work is properly cited (http://creativecommons.org/licenses/by/4.0/deed.en).

Received: 27.07 .2018

Accepted: 20.08.2018; Published: 30.09 .2018 